Article

\title{
How Are Unemployed Individuals with Obesity Affected by an Economic Crisis?
}

\author{
Manel Antelo ${ }^{1}$, Pilar Magdalena ${ }^{2}$, Juan C. Reboredo ${ }^{1}$ and Francisco Reyes-Santias ${ }^{3, *}$ \\ 1 Facultad de Ciencias Económicas, Universidade de Santiago de Compostela, 15782 Santiago de Compostela, \\ Spain; manel.antelo@usc.es (M.A.); juancarlos.reboredo@usc.es (J.C.R.) \\ 2 Hospital Povisa, 36211 Vigo, Spain; mmagdalenal@gmail.com \\ 3 Facultad de Ciencias Empresariales y Turismo, GEN, Universidade de Vigo, 32004 Ourense, Spain \\ * Correspondence: francisco.reyes@uvigo.es
}

Received: 1 February 2020; Accepted: 11 March 2020; Published: 13 March 2020

check for updates

\begin{abstract}
Objective: The purpose of this study was to measure the extent to which the advent of an economic crisis affects the magnitude of the impact of unemployment on obesity prevalence (IUOP). Methods: Using data corresponding to a boom period and a bust period of the Spanish economy, we calculated the IUOP in the Spanish population aged 16-65 years using propensity score matching, and using the difference-in-differences approach, analyzed to what extent the advent of an economic crisis affected the magnitude of such an IUOP. Results: The results point to significant differences in the body mass index (BMI) values of Spanish unemployed individuals depending on the phase of the economic cycle. Compared to a period of economic boom, a bust period increases the (log) BMI values of unemployed people by $0.22 \%$ and the (log) BMI of long-term unemployed people by a further $0.011 \%$. Conclusions: The design of health policies for the treatment and prevention of adult obesity should be tailored to the phase of the economic cycle and focus especially on the long-term unemployed individuals.
\end{abstract}

Keywords: unemployment; adult obesity; boom; bust; matching techniques; difference-in-difference

\section{Introduction}

That labor market status, and particularly involuntary job loss, have an impact on obesity prevalence in affected individuals has been widely documented [1-8]. However, less well understood is how this impact operates in different phases of the economic cycle: In other words, is impact the same or different in a boom versus bust period, when unemployment rate and duration oscillate considerably from one to other? We aimed to answer this question empirically by estimating and comparing the impact of unemployment on obesity prevalence (IUOP) in a boom and a bust period. Our target population to carry out this research was active Spanish adults, defined as employed or unemployed individuals aged $16-65$ years.

The question of whether or not the IUOP in Spanish adults differs in boom and bust times is of relevance for a number of reasons. If unemployment is a major determinant of body mass index (BMI), then an analysis of the IUOP in boom and bust periods would be useful, given that: (a) Adult obesity prevalence in Spain is among the highest in the developed world and is growing (prevalence in active Spanish adults aged 16-65 years increased from 12.4\% in 2006-2007-a period characterized by an economic boom) to $14.5 \%$ in 2011-2012-a bust period); and (b) the global economic crisis unleashed in 2008 particularly affected the Spanish economy, which saw unemployment rates rocket (from a mere $8.3 \%$ in 2006-a historically low rate for Spain - to $22.6 \%$ in 2011).

To perform our analysis, we obtained data from Spanish National Health Surveys carried out in June 2006-June 2007 and July 2011-June 2012 by the Spanish Ministry of Health, Social Services 
and Equality, the Institute of Health Information and the National Statistics Institute. Clearly, the period in which the first survey was conducted corresponds to a boom period of the Spanish economy and that in which the second survey was performed belongs to a bust period. The collected data covered health, lifestyle and socioeconomic and geographic characteristics for active adults only. We used propensity score matching (PSM) techniques to analyze the impact of unemployment on BMI, and difference-in-differences $(\mathrm{DiD})$ techniques to examine whether the economic crisis reinforced or dampened the magnitude of the IUOP. Both models were applied to all unemployed individuals in our sample and also to sub-samples reflecting certain unemployment duration categories.

Our findings show that IUOP magnitude differs during boom and bust periods; while the IUOP is not significant in a boom period, an economic crisis increases obesity levels in individuals who were unemployed during the boom period and especially in those who belong to two unemployment duration categories: Long-term unemployed individuals and recently unemployed individuals. As a result, it can be concluded that public policies to combat and prevent obesity should be tailored according to the phase of the economic cycle in which they are applied.

\section{Background}

Adult overweight and obesity—classically defined as an imbalance between energy consumed through dietary intake and energy expended through metabolism and physical activity-are serious health problems as reflected in alarming figures worldwide. According to the world's largest obesity study [9], around one in ten men and one in seven women are now affected by obesity. In 2014, 266 million men and 375 million women worldwide were affected by obesity, with people adding on around $1.5 \mathrm{~kg}$ per decade since 1975 . The same study predicted, based on these trends, (a) that $18 \%$ of the world's men and $21 \%$ of women would be affected by obesity by 2025 , and (b) that the World Health Organization (WHO) global obesity target of no rise in obesity above 2010 levels by 2025 is very unlikely to be achieved (see https://www.imperial.ac.uk/news/171536/worlds-obese-population\%20hits-640-million/).

The consequences of obesity have been spelled out: It is associated with more deaths than malnutrition, and it is a major risk factor for non-communicable conditions, such as cardiovascular disease, diabetes, musculoskeletal disorders, and certain cancers (primarily, endometrial, breast, and colon) [10].

In Europe, it is anticipated that adult obesity will reach crisis proportions by 2030' with severity varying across Europe [11]. Spain is predicted to be one of the most affected countries, as obesity is expected to affect as many as one in three Spaniards. Indeed, the prevalence rate of $17 \%$ for Spaniards aged 18 years and older are already unacceptably high [12] — having increased steadily from $7.4 \%$ three decades ago (Spanish National Health Surveys).

The causes of overweight and obesity in adults are manifold. Although genetic factors do play a role, little physical activity and poor lifestyle choices seem to be major determining factors [13]. Certain socioeconomic and demographic variables are also important determinants of obesity, namely, education [14], sex [15], age [16], income [17,18], and marital status [19-21]. Likewise, research in developed countries points to a strong association between economic conditions and health [22]; for instance, during temporary economic downturns, smoking and height-adjusted weight decline and leisure-time physical activity rises. Why behaviors become healthier when economic performance weakens may be explained by reduced hours spent at work, which, in turn, increases the non-market time available for lifestyle investments [22].

One factor assumed to have important social and economic consequences for adulthood obesity is labor market status. The reduced income implied by involuntary job loss may impact negatively on health, as it frequently results in individuals consuming obesogenic diets [1,2]. Long-term unemployment, in particular, seems to be a major risk factor for obesity prevalence [3-8]. The obesity risk when unemployed increases significantly, the longer the duration of unemployment and the older the individual [23]. Komlos and Carson [24] found that US prison inmates incarcerated in the 
depression-hit 1930s had significantly lower BMI values (up to 1.01 units) than inmates incarcerated in the late 19th century, a reduction attributed to the high unemployment levels of the period; in contrast, the BMI values of military college cadets in the 1930s increased by 1.5 units.

The health economics literature tends to point out that, beyond the impact on obesity prevalence, involuntary job loss causes a general deterioration in health [25-29]. However, in a study of the 2008 economic recession in Iceland, Ásgeirsdóttir, Corman, Noonan and Reichman [30] found that most health behaviors reverted to pre-crisis levels or trends during the economic recovery, suggesting that changes resulting from the crisis were probably too short-lived to have any major impact on health. A notable exception, however, was alcohol consumption, which did not revert back to the pre-crisis upward trend. Crost and Friedson [31] explored the impact of education-specific unemployment rates on mortality as a more exact measure of the likelihood of an individual is directly affected by a recession, finding that the unemployment rate of an education group was positively related to mortality in that group. This is consistent with the hypothesis that, while the overall unemployment level may have indirect health benefits, being directly affected by a recession has a detrimental effect on health. Finally, Caliendo and Lee [32] explored whether obese job applicants were treated or behaved differently from non-obese applicants, finding that only women who were obese experienced labor market discrimination (despite investing greater efforts in job-seeking) and also that this sub-group, once employed, earned significantly lower wages than healthy-weight women.

Zdrojowy-Wełna et al. [33] found that unemployment was a determinant of obesity for females, whereas, Noh et al. [34] pointed out that unemployment at age 60 or older, as well as women's unemployment, is associated with an increase in BMI compared to the unemployment of young people or men, respectively. Likewise, in a study developed to understand the epidemic situation of overweight and obesity among couples in planned pregnancy in the city of Chongqing (China), Liu et al. [35] identified that unemployment was more prone to overweight. In parallel, Coll et al. [36] aiming at evaluating a ten-year trend (2000-2010) in the prevalence of overweight among women in the Balearic Islands (Spain) and their association with socioeconomic factors, identify overweight and/or obesity increasing among young women, with unemployment. Moreover, Monsivais et al. [37] studying weight changes associated with job loss, retirement and job retention in two samples of adults working in the United Kingdom found that in two samples of adult workers revealed strong associations between job loss and excessive weight gain. Hughes and Kumari [38] showed that unemployment-adiposity relationship could not be properly studied assuming unidirectionality of effects, suggesting that unemployment could affect health via divergent adiposity-mediated pathways. However, Okop et al. [39] in determining the factors associated with excess body fat in black African men and women living in rural and urban communities in South Africa found that unemployment did not predict excessive body fat in men or women. Finally, Norte et al. [40] studying how socioeconomic changes have modified BMI values and eating habits of the Spanish population found that the employment situation is the variable that showed the greatest differences between years, while in a boom period, being unemployed did not represent a risk of having a poor diet.

What the current research adds to the health economics literature is that unemployment status-and to a significant degree, long-term unemployment-increases the BMI values of unemployed Spanish adults during the bust period more than during the boom period. More specifically, whereas, the IUOP is non-significant during a boom period, this no longer holds during a bust period, when the (log) BMI values of unemployed people increased by $0.22 \%$. Furthermore, the likelihood of obesity increasing during a bust period is greatest for long-term unemployed individuals (an additional $0.011 \%$ in the BMI values). The DiD model we used confirms this aggravation of the IUOP during a recession. These findings point to the need for public policy measures during an economic crisis to prevent and treat obesity in unemployed adults, and especially in long-term unemployed adults. Measures to promote healthy lifestyles should, in particular, target unemployed individuals with a low education level living a sedentary life. 
The results provided in this paper parallel previous findings from the health economics literature, indicating that an economic recession tends to increase obesity prevalence $[18,41,42]$, and to induce unhealthy habits that promote obesity [43]. Our results also allow us to conclude that unemployment, and especially long-term unemployment, represents a huge cost for individuals-in terms of poorer health and lowered life expectancy-and for the economy as a whole, beyond the negative multiplier effects, the loss of income and the increase in spare economic capacity. Our findings highlight the need for public unemployment and health policies that are specifically tailored to economic-cycle phase as a means to better prevent adult obesity, rather than policies with a long term scope, and thus, less flexible to differentiate a period of economic boom from one of recession.

\section{Methods}

Below we briefly describe the empirical approach used to account for the causal effects of an economic crisis on the magnitude of the IUOP. As in previous studies on the impact of unemployment on health variables [44,45], we used PSM techniques to disentangle the IUOP, and DiD approach to check how the advent of a bust period conditions the impact of unemployment on obesity prevalence. Furthermore, we also analyze whether the intensity of the IUOP differs across BMI quantiles by combining the $\mathrm{DiD}$ regression and quantile regression techniques.

\subsection{Propensity Score Matching}

PSM methods were introduced by Rosenbaum and Rubin [46] to reduce the impact of treatment-selection bias in estimating the causal treatment effect of a variable using observational data. We used this approach to measure the IUOP.

Let $Y_{1}\left(Y_{0}\right)$ denote the BMI of an unemployed (employed) individual, and let $D$ be a binary "treatment" indicator that takes the value $1(0)$ if the individual is unemployed (employed). Thus, $Y_{1}-Y_{0}$ measures whether unemployment has an impact on an individual's BMI. Since unemployment is the treatment effect, our primary goal is to estimate the average treatment effect on the treated (ATT), i.e., the average gain from treatment for individuals who were actually treated. This can be formally stated as:

$$
\mathrm{ATT}=E\left[Y_{1}-Y_{0} / D=1\right]=E\left[Y_{1} / D=1\right]-E\left[Y_{0} / D=1\right],
$$

where the term $E\left[Y_{0} / D=1\right]$ —called the counterfactual—accounts for what an unemployed individual's BMI would be if employed. To identify average unobserved counterfactuals, we used logit regressions for the boom period and the bus period, taking a vector $X$ of observable characteristics that are assumed to capture all differences between treated (unemployed) and non-treated (employed) individuals. We imposed the common support condition on treated units [47], that is, we did not consider treated individuals with a probability of being treated that was greater (lesser) than the highest (lowest) probability for the non-treated group. Although we used different matching methods for robustness purposes (e.g., k-nearest neighbor, kernel with a normal distribution), we only report evidence for matching with a Gaussian kernel. We also report results for short- and long-term unemployment and considering different BMI distribution interquartile ranges, namely, $0-0.05,0.05-0.1,0.1-0.25,0.25-0.5$, $0.5-0.75,0.75-0.9,0.9-0.95$, and $0.95-1$.

\subsection{Difference-in-Differences Framework}

We used the DiD approach to account for how the magnitude of the IUOP was affected by the economic crisis. We pooled BMI data for a boom period (the data collected by the 2006-2007 survey) and a bust period (the data collected by the 2011-2012 survey) with different (un)employment categories and different socioeconomic parameters, included in a vector $X$ of explanatory variables, and ran the following regression model:

$$
Y_{i}=\alpha+\delta D_{i}+\lambda t_{i}+\gamma D_{i} t_{i}+X_{i}^{\prime} \beta+\varepsilon_{i}
$$


where $Y_{i}$ measures the BMI of individual $i, D_{i}$ is a binary variable that takes the value $1(0)$ if individual $i$ is unemployed (employed), $t_{i}$ is a binary time variable that adopts the value 0 (1) if individual $i$ is observed in the boom (bust) period, and $\varepsilon_{i}$ is a stochastic variable with zero mean that is independent of regressors. On the other hand, parameter $\beta$ accounts for the socioeconomic variables included in vector $X_{i}$ that could affect BMI, whereas parameters $\delta$ and $\delta+\lambda+\gamma$ reflect the magnitude of the IUOP in the boom and bust period, respectively. The sign and significance of parameter $\gamma$, therefore, provide information on how the economic crisis affects the magnitude of the IUOP. The DiD estimator assumes common trends. Hence, conditional on the observables $X_{i}$, "controls evolve from a pre- to a post-program period as treatments would have evolved had they not been treated" [48].

Equation (2) was estimated using: (a) A non-matched sample that included all observations in either boom or bust periods for unemployed and employed individuals; and (b) a matched sample obtained from a kernel-based propensity score. In the latter case, given repeated cross-sectional data and following Blundell and Dias [48], we estimated propensity scores as a function of observable characteristics in vector $X$, using a logit model in which the dependent variable was equal to 1 if the subject was unemployed in the bust period and 0 otherwise. We used estimated propensity scores to calculate three sets of kernel weights for the employed group in the boom period, the employed group in the bust period and the unemployed group in the boom period. We then estimated Equation (2) with the matched sample in order to obtain a matching-DiD estimate of the effect of the economic crisis on the magnitude of the IUOP. We imposed the common support condition and restricted the analysis to treated observations which had a counterfactual in each of the three control samples [49].

\subsection{Difference-in-Differences Framework Via Quantile Regression}

We also assessed whether the crisis affected the intensity of the IUOP differently across BMI quantiles. We estimated the $\mathrm{DiD}$ regression in Equation (2) using a quantile regression technique [50], considering that the conditional $\tau$ quantile of BMI, $Q_{Y_{i}}\left(\tau \mid D_{i}, t_{i}, X_{i}\right)$ is given by:

$$
Q_{Y_{i}}\left(\tau \mid D_{i}, t_{i}, X_{i}\right)=\alpha_{\tau}+\delta_{\tau} D_{i}+\lambda_{\tau} t_{i}+\gamma_{\tau} D_{i} t_{i}+X_{i}^{\prime} \beta_{\tau}
$$

where, for quantile $\tau$, parameters $\delta_{\tau}$ and $\delta_{\tau}+\lambda_{\tau}+\gamma_{\tau}$ quantify the IUOP during boom and bust periods, respectively. All the parameters included in Equation (3) were estimated by minimizing the weighted absolute deviation as:

$$
\operatorname{argmin}_{\left(\alpha_{\tau}, \delta_{\tau}, \lambda_{\tau}, \gamma_{\tau}, \beta_{\tau}\right)} \sum_{i=1}^{N} \rho_{\tau}\left(Y_{i}-\alpha_{\tau}-\delta_{\tau} D_{i}-\lambda_{\tau} t_{i}-\gamma_{\tau} D_{i} t_{i}-X_{i}^{\prime} \beta_{\tau}\right),
$$

where $\rho_{\tau}(u)=u(\tau-I(u<0))$ for $0<\tau<1, I(\cdot)$ denotes the indication function, and $N$ stands for the number of individuals in the sample. We solved the problem defined in Equation (4) using the linear programming algorithm proposed by Koenker and D'Orey [51], while standard errors for the estimated parameters were computed using the bootstrapping procedure proposed by Buchinsky [52]. Finally, we estimated Equation (3) using both a non-matched sample and a matched sample from PSM as done for the DiD approach outlined above.

\section{Data Collection}

Our data were obtained from Spanish National Health Surveys conducted in June 2006-June 2007 and July 2011-June 2012. The first survey clearly corresponds to a boom period of the Spanish economy and the second one to a bust period. Both surveys-which apply stratified multistage sampling to annually sample around 29,000 households in Spain-retrieve information on individual health, lifestyle and socioeconomic and geographical characteristics. Restricting our sample to active individuals aged 16-65 years, we obtained a sample of 13,783 individuals for 2006-2007 (the so-called boom period) and 10,830 individuals for 2011-2012 (the so-called bust period), geographically located 
in all the Spanish autonomous regions. For each individual, we computed BMI as weight in kilograms divided by the square of height in meters, and following standard international criteria [53], obesity was computed in terms of BMI as a binary variable that took the value 1 (affected by obesity) if the BMI value was above a cutoff value, and 0 (non-affected by obesity) otherwise, with the cutoff determined according to the International Obesity Taskforce BMI cutoff tables [54].

For each individual we obtained information as follows: Employment status (employed or unemployed); unemployment duration if unemployed; educational level (no education, primary, secondary or university); age, sex and marital status; physical activity level; self-reported health status (labelled "health" in this study); weekly consumption of selected foods; and the Spanish autonomous region of residence.

Table 1 shows descriptive statistics for the sample for the representative boom and bust periods (years 2006-2007 and 2011-2012, respectively). Between both periods, obesity prevalence increased from $12.4 \%$ to $14.5 \%$ and mean BMI increased from 25.3 to 25.6 , while overall employment fell from $88.1 \%$ to $77.1 \%$ and long-term unemployment rose considerably, from $4.1 \%$ to $11.3 \%$. Obesity rates differed according to labor market status (Table 2). Obesity rates for employed people remained almost constant over the boom and bust periods, whereas, obesity rates for unemployed people, independently of unemployment duration, rose.

Table 1. Definition of variables and descriptive statistics for 2006-2007 (boom period) and 2011-2012 (bust period).

\begin{tabular}{|c|c|c|c|c|}
\hline Variable & Definition & $\begin{array}{c}2006-2007 \\
(N=13,783) \\
\text { Mean }^{\mathrm{a}}\end{array}$ & $\begin{array}{c}2011-2012 \\
(N=10,830) \\
\text { Mean }^{a}\end{array}$ & \\
\hline BMI & Body mass index & $25.3(4.193)$ & $25.6(4.256)$ & $(* *)$ \\
\hline$(\log ) \mathrm{BMI}$ & Logarithm of BMI & $3.2(0.001)$ & $3.2(0.002)$ & $(* *)$ \\
\hline Obesity & Dummy variable: 1 , obese; 0 , otherwise & 12.414 & 14.497 & $(* *)$ \\
\hline \multicolumn{5}{|l|}{ Labor status } \\
\hline Employed & Dummy variable: 1 , employed; 0 , otherwise & 88.116 & 77.091 & $(* *)$ \\
\hline Unemp_never worked & $\begin{array}{l}\text { Dummy variable: } 1 \text {, unemployed and never worked; } 0 \text {, } \\
\text { otherwise }\end{array}$ & 0.566 & 0.988 & $(* *)$ \\
\hline$<6$ months unemployed & $\begin{array}{l}\text { Dummy variable: } 1 \text {, unemployed }<6 \text { months; } 0 \text {, } \\
\text { otherwise }\end{array}$ & 5.202 & 6.805 & $(* *)$ \\
\hline 6-12 months unemployed & $\begin{array}{l}\text { Dummy variable: } 1 \text {, unemployed } 6-12 \text { months; } 0 \text {, } \\
\text { otherwise }\end{array}$ & 1.654 & 3.638 & $(* *)$ \\
\hline $\begin{array}{l}>12 \text { months unemployed } \\
\text { Socioeconomic status }\end{array}$ & $\begin{array}{l}\text { Dummy variable: } 1 \text {, unemployed >12 months; } 0 \text {, } \\
\text { otherwise }\end{array}$ & 4.099 & 11.330 & $(* *)$ \\
\hline Age & Age in years & $40.3(0.092)$ & $41.9(0.103)$ & $(* *)$ \\
\hline Male & Dummy variable: 1 , male; 0 , otherwise & 48.349 & 54.515 & $(* *)$ \\
\hline Health & Dummy variable: 1 , vision good; 0 , otherwise & 76.638 & 81.237 & $(* *)$ \\
\hline Health regular & Dummy variable: 1 , vision regular; 0 , otherwise & 19.060 & 15.125 & $(* *)$ \\
\hline Health poor & Dummy variable: 1 , vision bad; 0 , otherwise & 4.302 & 3.638 & $(* *)$ \\
\hline Marital status & Dummy variable: 1 , not single; 0 , otherwise & 65.733 & 64.441 & $(* *)$ \\
\hline No education & Dummy variable: 1 , no education; 0 , otherwise & 3.026 & 3.093 & \\
\hline Primary education & $\begin{array}{l}\text { Dummy variable: } 1 \text {, completed primary education; } 0 \text {, } \\
\text { otherwise } \\
\text { Dummy variable: } 1 \text {, completed secondary education; } 0\end{array}$ & 47.203 & 51.348 & $(* *)$ \\
\hline Secondary education & otherwise otherwise & 26.112 & 22.946 & $(* *)$ \\
\hline University education & $\begin{array}{l}\text { Dummy variable: } 1 \text {, completed university education; } 0 \text {, } \\
\text { otherwise }\end{array}$ & 23.660 & 22.613 & $(*)$ \\
\hline Physical activity & Dummy variable: 1 , physically active; 0 , otherwise & 58.550 & 25.642 & $(* *)$ \\
\hline Fruit & $\begin{array}{l}\text { Dummy variable: } 1 \text {, if } 3 \text { or more times/week to daily; } 0 \text {, } \\
\text { otherwise }\end{array}$ & 79.830 & 78.901 & $(*)$ \\
\hline Meat & $\begin{array}{l}\text { Dummy variable: } 1 \text {, if } 3 \text { or more times/week to daily; } 0 \text {, } \\
\text { otherwise }\end{array}$ & 75.383 & 68.818 & $(* *)$ \\
\hline Eggs & $\begin{array}{l}\text { Dummy variable: } 1 \text {, if } 3 \text { or more times/week to daily; } 0 \text {, } \\
\text { otherwise times a week to daily; } 0 \text {, otherwise } \\
\text { Dummy variable: } 1 \text {, if } 3 \text { or more times/week to daily; } 0 \text {, }\end{array}$ & 29.137 & 26.519 & $(* *)$ \\
\hline Fish & otherwise times a week to daily; 0 , otherwise & 40.499 & 37.313 & $(* *)$ \\
\hline Pasta & $\begin{array}{l}\text { Dummy variable: } 1 \text {, if } 3 \text { or more times/week to daily; } 0 \text {, } \\
\text { otherwise times a week to daily; } 0 \text {, otherwise }\end{array}$ & 96.409 & 94.922 & $(* *)$ \\
\hline Vegetables & $\begin{array}{l}\text { Dummy variable: } 1 \text {, if } 3 \text { or more times/week to daily; } 0 \text {, } \\
\text { otherwise times a week to daily; } 0 \text {, otherwise }\end{array}$ & 80.062 & 83.564 & $\left({ }^{* *}\right)$ \\
\hline
\end{tabular}


Table 1. Cont.

\begin{tabular}{|c|c|c|c|c|}
\hline Variable & Definition & $\begin{array}{c}2006-2007 \\
(N=13,783) \\
\text { Mean }^{\mathrm{a}}\end{array}$ & $\begin{array}{c}2011-2012 \\
(N=10,830) \\
\text { Mean }^{a}\end{array}$ & \\
\hline Sausages & $\begin{array}{l}\text { Dummy variable: } 1 \text {, if } 3 \text { or more times/week to daily; } 0 \text {, } \\
\text { otherwise times a week to daily; } 0 \text {, otherwise }\end{array}$ & 43.118 & 38.984 & $(* *)$ \\
\hline Milk & $\begin{array}{l}\text { Dummy variable: } 1 \text {, if } 3 \text { or more times/week to daily; } 0 \text {, } \\
\text { otherwise times a week to daily; } 0 \text {, otherwise }\end{array}$ & 94.464 & 92.207 & $(* *)$ \\
\hline Sugars & $\begin{array}{l}\text { Dummy variable: } 1 \text {, if } 3 \text { or more times/week to daily; } 0 \text {, } \\
\text { otherwise times a week to daily; } 0 \text {, otherwise }\end{array}$ & 47.972 & 44.515 & $(* *)$ \\
\hline Soda & $\begin{array}{l}\text { Dummy variable: } 1 \text {, if } 3 \text { or more times/week to daily; } 0 \text {, } \\
\text { otherwise times a week to daily; } 0 \text {, otherwise } \\
\text { Dummy variable: } 1 \text {, if resident in Andalusia; } 0 \text {, }\end{array}$ & 26.968 & 23.666 & $(* *)$ \\
\hline Region 1 & otherwise & 8.024 & 12.115 & $(* *)$ \\
\hline Region 2 & Dummy variable: 1 , if resident in Aragon; 0 , otherwise & 9.410 & 3.804 & $(* *)$ \\
\hline Region 3 & $\begin{array}{l}\text { Dummy variable: } 1 \text {, if resident in Asturias; } 0 \text {, } \\
\text { otherwise }\end{array}$ & 2.808 & 3.416 & $(* *)$ \\
\hline Region 4 & $\begin{array}{l}\text { Dummy variable: } 1 \text {, if resident in Balearic Islands; } 0 \text {, } \\
\text { otherwise }\end{array}$ & 6.798 & 3.638 & $(* *)$ \\
\hline Region 5 & $\begin{array}{l}\text { Dummy variable: } 1 \text {, if resident in Canarias; } 0 \text {, } \\
\text { otherwise }\end{array}$ & 4.484 & 5.466 & $(* *)$ \\
\hline Region 6 & $\begin{array}{l}\text { Dummy variable: } 1 \text {, if resident in Cantabria; } 0 \text {, } \\
\text { otherwise }\end{array}$ & 5.674 & 2.650 & $(* *)$ \\
\hline Region 7 & $\begin{array}{l}\text { Dummy variable: } 1 \text {, if resident in Castilla-Leon; } 0 \text {, } \\
\text { otherwise } \\
\text { Dummy variable: } 1 \text {, if resident in Castilla-La Mancha; }\end{array}$ & 3.932 & 5.577 & $(* *)$ \\
\hline Region 8 & 0 , otherwise otherwise & 3.359 & 4.377 & $(* *)$ \\
\hline Region 9 & $\begin{array}{l}\text { Dummy variable: } 1 \text {, if resident in Catalonia; } 0 \text {, } \\
\text { otherwise }\end{array}$ & 7.255 & 11.099 & $(* *)$ \\
\hline Region 10 & $\begin{array}{l}\text { Dummy variable: } 1 \text {, if resident in Valencia; } 0 \text {, } \\
\text { otherwise }\end{array}$ & 6.675 & 8.772 & $(* *)$ \\
\hline Region 11 & $\begin{array}{l}\text { Dummy variable: } 1 \text {, if resident in Extremadura; 0, } \\
\text { otherwise }\end{array}$ & 2.714 & 4.211 & $(* *)$ \\
\hline Region 12 & Dummy variable: 1 , if resident in Galicia; 0 , otherwise & 10.187 & 4.986 & $(* *)$ \\
\hline Region 13 & Dummy variable: 1 , if resident in Madrid; 0 , otherwise & 8.119 & 10.323 & $(* *)$ \\
\hline Region 14 & Dummy variable: 1 , if resident in Murcia; 0 , otherwise & 6.254 & 4.192 & $(* *)$ \\
\hline Region 15 & Dummy variable: 1 , if resident in Navarre; 0 , otherwise & 6.225 & 3.980 & $(* *)$ \\
\hline Region 16 & $\begin{array}{l}\text { Dummy variable: } 1 \text {, if resident in Basque Country; } 0 \text {, } \\
\text { otherwise }\end{array}$ & 3.998 & 5.873 & $(* *)$ \\
\hline Region 17 & Dummy variable: 1 , if resident in Rioja; 0 , otherwise & 2.677 & 3.398 & $(* *)$ \\
\hline Region 18 & $\begin{array}{l}\text { Dummy variable: } 1 \text {, if resident in Ceuta or Melilla; } 0 \text {, } \\
\text { otherwise }\end{array}$ & 1.408 & 2.124 & $(* *)$ \\
\hline
\end{tabular}

Note: Sample of Spanish employed and unemployed people aged 16-65 years from the Spanish Health Surveys.

${ }^{a}$ Data are reported as percentages for the categorical variables and as means (standard deviations) for the continuous variables. * and ** denote significant differences in means or in categories between 2006-2007 (boom period) and 2011-2012 (bust period) according to the $t$-test (continuous variables) or chi-square test (categorical variables) at the $10 \%$ and $5 \%$ level, respectively.

Table 2. Obesity percentages by labor market status for 2006-2007 (boom period) and 2011-2012 (bust period).

\begin{tabular}{cccc}
\hline Obesity (\%) & 2006-2007 & 2011-2012 & \\
\hline Employed & 12.194 & 13.523 & $\left(^{* *}\right)$ \\
Never worked & 12.821 & 13.084 & \\
Unemployed & 14.042 & 17.775 & $\left(^{* *}\right)$ \\
$<6$ months & 12.552 & 15.197 & \\
6-12 months & 13.158 & 18.020 & \\
>12 months & 15.929 & 19.641 & $\left.\mathbf{*}^{*}\right)$ \\
Total & 12.414 & 14.497 & \\
\hline
\end{tabular}

Note: * and ** denote significant differences at the $10 \%$ and $5 \%$ level, respectively, in obesity prevalence between employed and unemployed individuals for the years 2006-2007 and 2011-2012 according to the chi-square test. Source: Spanish Health Surveys 2006-2007 $(N=13,783)$ and 2011-2012 $(N=10,830)$.

The same trend was reflected in BMI terms (Table 3). Note that the level of physical exercise fell significantly during the bust period, whereas, no significant changes occurred in food consumption or in other socioeconomic variables. 
Table 3. BMI and (log) BMI values in relation to employment status for 2006-2007 and 2011-2012.

\begin{tabular}{|c|c|c|c|c|c|c|}
\hline & \multicolumn{3}{|c|}{ 2006-2007 } & \multicolumn{3}{|c|}{ 2011-2012 } \\
\hline & Employed & Unemployed & & Employed & Unemployed & \\
\hline BMI & 25.335 & 25.148 & $(* *)$ & 25.516 & 25.912 & $(* *)$ \\
\hline (log) BMI & 3.220 & 3.210 & $(* *)$ & 3.227 & 3.240 & $(* *)$ \\
\hline
\end{tabular}

Note: ${ }^{* *}$ denotes significant differences at the $5 \%$ level in mean BMI between employed and unemployed individuals for the years 2006-2007 and 2011-2012 according to the $t$-test.

\section{Results and Discussion}

Below we first report boom and bust results regarding significant differences in average and (log) BMI for unemployed and employed individuals and in obesity prevalence for unemployed and employed individuals (see Tables 2 and 3 above). The chi-square test and the $t$-test for differences in obesity prevalence and differences in mean BMI, respectively, confirmed significant differences in BMI values for employed versus unemployed individuals in the different phases of the economic cycle.

\subsection{Evidence Regarding Average Treatment Effect on the Treated}

Empirical results for the ATT (Gaussian kernel) for employed (non-treated) individuals and unemployed (treated) individuals in the boom and bust periods are reported in Table 4 .

Table 4. Estimates of the unemployment effect on (log) BMI values for 2006-2007 (boom period) and 2011-2012 (bust period).

\begin{tabular}{|c|c|c|c|c|c|c|c|c|}
\hline & \multicolumn{4}{|c|}{ 2006-2007 } & \multicolumn{4}{|c|}{ 2011-2012 } \\
\hline & $\begin{array}{l}\text { Unemployed } \\
\text { (average) }^{\text {a }} \\
E\left(Y_{1} \mid D=1\right)\end{array}$ & $\begin{array}{c}\text { Estimated } \\
\text { counterfactual } \\
\text { (average) }^{\mathrm{b}} \\
E\left(Y_{0} \mid D=1\right)\end{array}$ & $\begin{array}{c}\text { Impact } \\
\text { (average) }^{c} \\
\text { ATT }\end{array}$ & t-statistic & $\begin{array}{l}\text { Unemployed } \\
\text { (average) }^{\mathrm{a}} \\
E\left(Y_{1} \mid D=1\right)\end{array}$ & $\begin{array}{c}\text { Estimated } \\
\text { counterfactual } \\
{\text { (average })^{\mathrm{b}}}^{E\left(Y_{0} \mid D=1\right)}\end{array}$ & $\begin{array}{c}\text { Impact } \\
{\text { (average })^{c}}^{c} \\
\text { ATT }\end{array}$ & t-statistic \\
\hline \multicolumn{9}{|c|}{ Panel A. Overall (log) BMI } \\
\hline & 3.210 & 3.214 & -0.005 & -1.02 & 3.240 & 3.232 & 0.007 & $1.87 *$ \\
\hline \multicolumn{9}{|c|}{ Panel B. (log) BMI by quantile range } \\
\hline $0-0.05$ & 2.924 & 2.926 & -0.002 & -0.33 & 2.911 & 2.921 & -0.010 & -1.56 \\
\hline $0.05-0.10$ & 2.997 & 2.998 & -0.001 & -0.69 & 3.004 & 3.006 & -0.002 & -1.41 \\
\hline $0.10-0.25$ & 3.065 & 3.066 & -0.001 & -0.74 & 3.079 & 3.078 & -0.000 & -0.14 \\
\hline $0.25-0.50$ & 3.159 & 3.161 & -0.002 & -1.15 & 3.174 & 3.173 & 0.001 & 0.51 \\
\hline $0.50-0.75$ & 3.264 & 3.263 & 0.000 & 0.04 & 3.275 & 3.274 & 0.001 & 0.78 \\
\hline $0.75-0.90$ & 3.366 & 3.366 & -0.001 & -0.25 & 3.380 & 3.378 & 0.003 & 1.36 \\
\hline $0.90-0.95$ & 3.450 & 3.455 & -0.005 & $-1.87^{*}$ & 3.468 & 3.470 & -0.002 & -0.80 \\
\hline 0.95-1 & 3.579 & 3.582 & -0.003 & -0.29 & 3.592 & 3.596 & -0.005 & -0.56 \\
\hline \multicolumn{9}{|c|}{ Panel C. (log) BMI by unemployment category } \\
\hline $\begin{array}{l}\text { Never } \\
\text { worked } \\
\text { employed } \\
\text { Unemployed }\end{array}$ & 3.163 & 3.209 & -0.046 & $-2.08 * *$ & 3.173 & 3.200 & -0.026 & -1.28 \\
\hline $\begin{array}{l}<6 \mathrm{~m} \\
\text { unemployed }\end{array}$ & 3.200 & 3.216 & -0.016 & $-2.49 * *$ & 3.235 & 3.227 & 0.009 & 1.42 \\
\hline $6-12 \mathrm{~m}$ & 3.218 & 3.219 & -0.001 & -0.08 & 3.234 & 3.228 & 0.009 & 0.74 \\
\hline$>12 \mathrm{~m}$ & 3.224 & 3.224 & -0.000 & -0.03 & 3.250 & 3.239 & 0.011 & $1.99 * *$ \\
\hline
\end{tabular}

Notes: We used matching methods with propensity score and a Gaussian kernel for a sample size of 13,783 individuals in 2006-2007 and 10,830 individuals in 2011-2012. * and ${ }^{* *}$ denote $p<0.10$ and $p<0.05$, respectively. Control variables: Age, sex, health (vision), marital status, education, physical activity, food consumption and region. a Sample data correspond to unemployed individuals. ${ }^{b}$ Estimates for unemployed if they had been working (counterfactual). ${ }^{\mathrm{c}}$ The average treatment effect (ATT) is given by column 2 minus column 3. Expressed as BMI units, it measures the change in mean BMI attributable to unemployment.

In Table 4, for each studied year, the first column reports (log) BMI values for unemployed individuals; the second column reports the counterfactual, i.e., (log) BMI if the unemployed individual was employed; the third column—showing differences between the two previous columns-reports the rise or fall in (log) BMI explained by unemployment (labelled ATT); and the final column reports statistical significance for the ATT estimates. 
Panel A in Table 4 shows ATT empirical evidence for total unemployment, indicating that when individuals became unemployed in the bust period, $(\log )$ BMI increased significantly (at the $10 \%$ significance level), whereas, the change was non-significant in the boom period. Taking into account the effect of the different factors reflected in the vector $X$, our results indicate that the impact of unemployment on BMI values was greater in magnitude in the bust period than in the boom period. Specifically, unemployment reduced (log) BMI levels by 0.005 in the boom period and increased (log) BMI levels by 0.007 in the bust period-reflecting a reduction of $0.16 \%$ and an increase of $0.22 \%$, respectively.

Panel B in Table 4 displays empirical ATT results for (log) BMI by interquartile range. The impact of unemployment on different (log) BMI interquartile ranges was concentrated among individuals in the upper interquartile ranges in the boom period, leaving individuals in the lower and median interquartile ranges unaffected by unemployment status. This negative effect may be explained by the fact that an unemployment shock in the short term may lead overweight or obese individuals to take better care of themselves and improve their appearance to facilitate finding a new job.

Panel $C$ in Table 4 reflects the effect of unemployment status on BMI values for different unemployment durations, indicating that the positive impact of unemployment status on $(\log )$ BMI values were reinforced with increased unemployment duration in the bust period. Thus, being unemployed for more than 12 months significantly increased (log) BMI values. These results corroborate previous studies that confirm poorer health among long-term unemployed individuals $[23,55]$. In the boom period, however, unemployment had the opposite effect on BMI values, i.e., (log) BMI values fell for short-term unemployed individuals (less than six months).

\subsection{Difference-in-Differences Evidence}

Tables 5 and 6 report the overall results for the impact of unemployment status on BMI—obtained using the DiD method reflected in Equation (2)—for the non-matched and matched samples (using Gaussian kernel matching for the refined control group), respectively.

Table 5. DiD estimates of the impact of unemployment on BMI for 2006-2007 (boom period) and 2011-2012 (bust period) using non-matched samples.

\begin{tabular}{llllll}
\hline Parameter & All & $\begin{array}{l}\text { Never } \\
\text { Employed }\end{array}$ & $\begin{array}{l}<6 \text { months } \\
\text { Unemployed }\end{array}$ & $\begin{array}{l}\mathbf{6} \text {-12 months } \\
\text { Unemployed }\end{array}$ & $\begin{array}{l}\text { >12 months } \\
\text { Unemployed }\end{array}$ \\
\hline Constant $(\alpha)$ & $3.098^{* * *}$ & $3.092^{* * *}$ & $3.094^{* * *}$ & $3.091^{* * *}$ & $3.095^{* * *}$ \\
& $(323.85)$ & $(291.98)$ & $(303.16)$ & $(296.32)$ & $(306.42)$ \\
IUOP in boom $(\delta)$ & -0.002 & 0.004 & -0.005 & 0.011 & -0.003 \\
& $(-0.38)$ & $(0.24)$ & $(-0.82)$ & $(1.12)$ & $(-0.44)$ \\
Bust effect $(\lambda)$ & $-0.008^{* * *}$ & $-0.008^{* * *}$ & $-0.008^{* * *}$ & $-0.008^{* * *}$ & $-0.008^{* * *}$ \\
& $(-3.63)$ & $(-3.61)$ & $(-3.78)$ & $(-3.62)$ & $(-3.45)$ \\
Bust effect on IUOP $(\gamma)$ & $0.010^{*}$ & -0.006 & $0.017^{* *}$ & -0.002 & 0.010 \\
Control variables & $(1.93)$ & $(-0.30)$ & $(2.15)$ & $(-0.16)$ & $(1.28)$ \\
Age & & & & & \\
& $0.003^{* * *}$ & $0.003^{* * *}$ & $0.003^{* * *}$ & $0.003^{* * *}$ & $0.003^{* * *}$ \\
Sex & $(32.92)$ & $(30.83)$ & $(32.02)$ & $(31.06)$ & $(30.86)$ \\
Health regular & $0.087^{* * *}$ & $0.091^{* * *}$ & $0.090^{* * *}$ & $0.090^{* * *}$ & $0.088^{* * *}$ \\
\multirow{3}{*}{ Health poor } & $(44.50)$ & $(43.75)$ & $(44.45)$ & $(43.74)$ & $(43.38)$ \\
& $0.020^{* * *}$ & $0.020^{* * *}$ & $0.019^{* * *}$ & $0.020^{* * *}$ & $0.020^{* * *}$ \\
Marital status & $(7.85)$ & $(9.12)$ & $(7.29)$ & $(7.42)$ & $(7.72)$ \\
& $0.025^{* * *}$ & $0.033^{* * *}$ & $0.032^{* * *}$ & $0.029 * * *$ & $0.026^{* * *}$ \\
Primary education & $(5.08)$ & $(5.89)$ & $(5.97)$ & $(5.45)$ & $(5.04)$ \\
& $0.020^{* * *}$ & $0.020^{* * *}$ & $0.020^{* * *}$ & $0.020 * *$ & $0.020^{* * *}$ \\
\hline
\end{tabular}


Table 5. Cont.

\begin{tabular}{|c|c|c|c|c|c|}
\hline Parameter & All & $\begin{array}{l}\text { Never } \\
\text { Employed }\end{array}$ & $\begin{array}{l}<6 \text { months } \\
\text { Unemployed }\end{array}$ & $\begin{array}{l}\text { 6-12 months } \\
\text { Unemployed }\end{array}$ & $\begin{array}{l}>12 \text { months } \\
\text { Unemployed }\end{array}$ \\
\hline Secondary education & $\begin{array}{l}-0.033^{* * *} \\
(-5.71)\end{array}$ & $\begin{array}{l}-0.032^{* * *} \\
(-4.81)\end{array}$ & $\begin{array}{l}-0.033^{* * *} \\
(-5.20)\end{array}$ & $\begin{array}{l}-0.030 * * * \\
(-4.69)\end{array}$ & $\begin{array}{l}-0.032^{* * *} \\
(-5.16)\end{array}$ \\
\hline University education & $\begin{array}{l}-0.058^{* * *} \\
(-9.86)\end{array}$ & $\begin{array}{l}-0.058^{* * *} \\
(-8.67)\end{array}$ & $\begin{array}{l}-0.058^{* * *} \\
(-9.13)\end{array}$ & $\begin{array}{l}-0.056^{* * *} \\
(-8.57)\end{array}$ & $\begin{array}{l}-0.056^{* * *} \\
(-9.06)\end{array}$ \\
\hline Physical activity & $\begin{array}{l}-0.018^{* * *} \\
(-8.69)\end{array}$ & $\begin{array}{l}-0.017^{* * *} \\
(-7.73)\end{array}$ & $\begin{array}{l}-0.017^{* * *} \\
(-7.99)\end{array}$ & $\begin{array}{l}-0.017 \text { *** } \\
(-7.87)\end{array}$ & $\begin{array}{l}-0.017^{* * *} \\
(-8.08)\end{array}$ \\
\hline Fruit & $\begin{array}{l}0.007^{* * *} \\
(2.66)\end{array}$ & $\begin{array}{l}0.005^{*} \\
(1.80)\end{array}$ & $\begin{array}{l}0.006^{* *} \\
(2.14)\end{array}$ & $\begin{array}{l}0.005^{* *} \\
(1.99)\end{array}$ & $\begin{array}{l}0.006^{* *} \\
(2.35)\end{array}$ \\
\hline Meat & $\begin{array}{l}0.017^{* * *} \\
(7.71)\end{array}$ & $\begin{array}{l}0.017^{* * *} \\
(7.04)\end{array}$ & $\begin{array}{l}0.016^{* * *} \\
(7.04)\end{array}$ & $\begin{array}{l}0.017^{* * *} \\
(7.35)\end{array}$ & $\begin{array}{l}0.017^{* * *} \\
(7.45)\end{array}$ \\
\hline Eggs & $\begin{array}{l}-0.006^{* * *} \\
(-2.84)\end{array}$ & $\begin{array}{l}-0.006^{* * *} \\
(-2.72)\end{array}$ & $\begin{array}{l}-0.007^{* * *} \\
(-3.02)\end{array}$ & $\begin{array}{l}-0.007^{* * *} \\
(-3.07)\end{array}$ & $\begin{array}{l}-0.007^{* * *} \\
(-2.88)\end{array}$ \\
\hline Fish & $\begin{array}{l}0.0020 \\
(1.00)\end{array}$ & $\begin{array}{l}0.003 \\
(1.23)\end{array}$ & $\begin{array}{l}0.001 \\
(0.49)\end{array}$ & $\begin{array}{l}0.003 \\
(1.26)\end{array}$ & $\begin{array}{l}0.003 \\
(1.48)\end{array}$ \\
\hline Pasta & $\begin{array}{l}-0.025^{* * *} \\
(-5.39)\end{array}$ & $\begin{array}{l}-0.024^{* * *} \\
(-4.70)\end{array}$ & $\begin{array}{l}-0.025^{* * *} \\
(-5.15)\end{array}$ & $\begin{array}{l}-0.023 * * * \\
(-4.71)\end{array}$ & $\begin{array}{l}-0.026^{* * *} \\
(-5.24)\end{array}$ \\
\hline Vegetables & $\begin{array}{l}0.005^{* *} \\
(1.97)\end{array}$ & $\begin{array}{l}0.005^{*} \\
(1.65)\end{array}$ & $\begin{array}{l}0.006^{* *} \\
(2.14)\end{array}$ & $\begin{array}{l}0.006^{* *} \\
(2.18)\end{array}$ & $\begin{array}{l}0.004 \\
(1.64)\end{array}$ \\
\hline Sausages & $\begin{array}{l}-0.003 \\
(-1.23)\end{array}$ & $\begin{array}{l}-0.002 \\
(-0.95)\end{array}$ & $\begin{array}{l}-0.002 \\
(-0.88)\end{array}$ & $\begin{array}{l}-0.002 \\
(-0.99)\end{array}$ & $\begin{array}{l}-0.002 \\
(-1.00)\end{array}$ \\
\hline Milk & $\begin{array}{l}0.003 \\
(0.88)\end{array}$ & $\begin{array}{l}0.004 \\
(0.95)\end{array}$ & $\begin{array}{l}0.005 \\
(1.11)\end{array}$ & $\begin{array}{l}0.004 \\
(1.07)\end{array}$ & $\begin{array}{l}0.004 \\
(0.93)\end{array}$ \\
\hline Sugars & $\begin{array}{l}-0.0144^{* * *} \\
(-7.44)\end{array}$ & $\begin{array}{l}-0.015^{* * *} \\
(-7.01)\end{array}$ & $\begin{array}{l}-0.014 \text { *** } \\
(-7.06)\end{array}$ & $\begin{array}{l}-0.015^{* * *} \\
(-7.39)\end{array}$ & $\begin{array}{l}-0.014^{* * *} \\
(-6.81)\end{array}$ \\
\hline Soda & $\begin{array}{l}0.002 \\
(0.75)\end{array}$ & $\begin{array}{l}0.002 \\
(0.80)\end{array}$ & $\begin{array}{l}0.002 \\
(0.71)\end{array}$ & $\begin{array}{l}0.003 \\
(1.09)\end{array}$ & $\begin{array}{l}0.002 \\
(0.84)\end{array}$ \\
\hline $\mathrm{R}^{2}$ & 0.18 & 0.19 & 0.19 & 0.19 & 0.18 \\
\hline
\end{tabular}

Notes: DiD model to estimate the impact of unemployment status on $(\log )$ BMI for a sample size of 24,613 individuals. Equation (2) was estimated by controlling for the variables reported in the table and for regional effects (not reported in the table, but available on request). ${ }^{*}, * *$ and ${ }^{* * *}$ denote significance at the $10 \%, 5 \%$ and $1 \%$ levels, respectively.

Table 6. DiD estimates with Gaussian kernel matching for the impact of unemployment on BMI for 2006-2007 (boom period) and 2011-2012 (bust period).

\begin{tabular}{|c|c|c|c|c|c|}
\hline Parameter & All & $\begin{array}{l}\text { Never } \\
\text { Employed }\end{array}$ & $\begin{array}{l}<6 \text { months } \\
\text { Unemployed }\end{array}$ & $\begin{array}{l}\text { 6-12 months } \\
\text { Unemployed }\end{array}$ & $\begin{array}{l}>12 \text { months } \\
\text { Unemployed }\end{array}$ \\
\hline Constant $(\alpha)$ & $\begin{array}{l}3.108^{* * *} \\
(332.44)\end{array}$ & $\begin{array}{l}3.113^{* * *} \\
(237.10)\end{array}$ & $\begin{array}{l}3.104^{* * *} \\
(306.72)\end{array}$ & $\begin{array}{l}3.091^{* * *} \\
(297.25)\end{array}$ & $\begin{array}{l}3.133^{* * *} \\
(310.18)\end{array}$ \\
\hline IUOP in boom $(\delta)$ & $\begin{array}{l}-0.002 \\
(-0.77)\end{array}$ & $\begin{array}{l}0.011^{* * *} \\
(2.64)\end{array}$ & $\begin{array}{l}-0.003 \\
(-1.16)\end{array}$ & $\begin{array}{l}0.011^{* * *} \\
(3.19)\end{array}$ & $\begin{array}{l}-0.006 \\
(-1.53)\end{array}$ \\
\hline Bust effect $(\lambda)$ & $\begin{array}{l}-0.007^{* *} \\
(-2.37)\end{array}$ & $\begin{array}{l}-0.008^{*} \\
(-1.87)\end{array}$ & $\begin{array}{l}-0.010^{* * *} \\
(-3.32)\end{array}$ & $\begin{array}{l}-0.008^{* * *} \\
(-2.69)\end{array}$ & $\begin{array}{l}-0.008^{* *} \\
(-2.20)\end{array}$ \\
\hline Bust effect on IUOP $(\gamma)$ & $\begin{array}{l}0.009^{* *} \\
(2.27)\end{array}$ & $\begin{array}{l}-0.010 * \\
(-1.83)\end{array}$ & $\begin{array}{l}0.015^{* * *} \\
(3.85)\end{array}$ & $\begin{array}{l}-0.001 \\
(-0.31)\end{array}$ & $\begin{array}{l}0.011 * * \\
(2.43)\end{array}$ \\
\hline \multicolumn{6}{|l|}{ Control variables } \\
\hline Age & $\begin{array}{l}0.003^{* * *} \\
(32.42)\end{array}$ & $\begin{array}{l}0.004^{* * *} \\
(30.24)\end{array}$ & $\begin{array}{l}0.003^{* * *} \\
(30.83)\end{array}$ & $\begin{array}{l}0.003 * * * \\
(30.05)\end{array}$ & $\begin{array}{l}0.003^{* * *} \\
(25.47)\end{array}$ \\
\hline Sex & $\begin{array}{l}0.076^{* * *} \\
(36.44)\end{array}$ & $\begin{array}{l}0.108^{* * * *} \\
(37.45)\end{array}$ & $\begin{array}{l}0.083^{* * * *} \\
(39.71)\end{array}$ & $\begin{array}{l}0.076^{* * * *} \\
(35.20)\end{array}$ & $\begin{array}{l}0.071^{* * * *} \\
(31.34)\end{array}$ \\
\hline Health regular & $\begin{array}{l}0.021^{* * *} \\
(8.31)\end{array}$ & $\begin{array}{l}0.010 * * \\
(2.44)\end{array}$ & $\begin{array}{l}0.017^{* * *} \\
(6.45)\end{array}$ & $\begin{array}{l}0.021 \text { *** } \\
(7.50)\end{array}$ & $\begin{array}{l}0.025^{* * *} \\
(9.51)\end{array}$ \\
\hline Health poor & $\begin{array}{l}0.018^{* * * *} \\
(4.29)\end{array}$ & $\begin{array}{l}0.059^{* * * *} \\
(7.90)\end{array}$ & $\begin{array}{l}0.027^{* * * *} \\
(4.97)\end{array}$ & $\begin{array}{l}0.006 \\
(1.18)\end{array}$ & $\begin{array}{l}0.016^{* * * *} \\
(3.84)\end{array}$ \\
\hline Marital status & $\begin{array}{l}0.020^{* * *} \\
(9.73)\end{array}$ & $\begin{array}{l}0.018^{* * *} \\
(6.30)\end{array}$ & $\begin{array}{l}0.021^{* * *} \\
(10.06)\end{array}$ & $\begin{array}{l}0.019 * * * \\
(8.70)\end{array}$ & $\begin{array}{l}0.016^{* * *} \\
(7.33)\end{array}$ \\
\hline Primary education & $\begin{array}{l}-0.010 * * \\
(-2.08)\end{array}$ & $\begin{array}{l}-0.035^{* * *} \\
(-5.14)\end{array}$ & $\begin{array}{l}-0.017^{* * *} \\
(-2.82)\end{array}$ & $\begin{array}{l}-0.004 \\
(-0.63)\end{array}$ & $\begin{array}{l}-0.009 * \\
(-1.91)\end{array}$ \\
\hline Secondary education & $\begin{array}{l}-0.033^{* * *} \\
(-6.34)\end{array}$ & $\begin{array}{l}-0.016^{* *} \\
(-2.14)\end{array}$ & $\begin{array}{l}-0.038^{* * *} \\
(-6.22)\end{array}$ & $\begin{array}{l}-0.018^{* * *} \\
(-2.95)\end{array}$ & $\begin{array}{l}-0.039^{* * *} \\
(-7.36)\end{array}$ \\
\hline
\end{tabular}


Table 6. Cont.

\begin{tabular}{|c|c|c|c|c|c|}
\hline Parameter & All & $\begin{array}{l}\text { Never } \\
\text { Employed }\end{array}$ & $\begin{array}{l}<6 \text { months } \\
\text { Unemployed }\end{array}$ & $\begin{array}{l}\text { 6-12 months } \\
\text { Unemployed }\end{array}$ & $\begin{array}{l}>12 \text { months } \\
\text { Unemployed }\end{array}$ \\
\hline University education & $\begin{array}{l}-0.057^{* * *} \\
(-10.37)\end{array}$ & $\begin{array}{l}-0.053^{* * *} \\
(-7.38)\end{array}$ & $\begin{array}{l}-0.063^{* * *} \\
(-10.05)\end{array}$ & $\begin{array}{l}-0.043^{* * *} \\
(-7.07)\end{array}$ & $\begin{array}{l}-0.058^{* * *} \\
(-10.21)\end{array}$ \\
\hline Physical activity & $\begin{array}{l}-0.022^{* * *} \\
(-9.46)\end{array}$ & $\begin{array}{l}-0.034^{* * *} \\
(-11.31)\end{array}$ & $\begin{array}{l}-0.019^{* * *} \\
(-8.77)\end{array}$ & $\begin{array}{l}-0.025^{* * *} \\
(-10.52)\end{array}$ & $\begin{array}{l}-0.023 * * * \\
(-9.02)\end{array}$ \\
\hline Fruit & $\begin{array}{l}0.011^{* * *} \\
(4.34)\end{array}$ & $\begin{array}{l}-0.011^{* * *} \\
(-3.20)\end{array}$ & $\begin{array}{l}0.009^{* * * *} \\
(3.48)\end{array}$ & $\begin{array}{l}0.007^{* * * *} \\
(2.87)\end{array}$ & $\begin{array}{l}0.013^{* * *} \\
(4.70)\end{array}$ \\
\hline Meat & $\begin{array}{l}0.017^{* * *} \\
(7.48)\end{array}$ & $\begin{array}{l}0.007^{* *} \\
(2.36)\end{array}$ & $\begin{array}{l}0.015^{* * *} \\
(6.28)\end{array}$ & $\begin{array}{l}0.027^{* * *} \\
(11.12)\end{array}$ & $\begin{array}{l}0.018^{* * *} \\
(7.22)\end{array}$ \\
\hline Eggs & $\begin{array}{l}-0.006^{* * * *} \\
(-2.43)\end{array}$ & $\begin{array}{l}0.029^{* * *} \\
(-9.36)\end{array}$ & $\begin{array}{l}-0.007^{* * *} \\
(-2.98)\end{array}$ & $\begin{array}{l}-0.010^{* * *} \\
(-4.17)\end{array}$ & $\begin{array}{l}-0.006^{* *} \\
(-2.42)\end{array}$ \\
\hline Fish & $\begin{array}{l}-0.000 \\
(-0.15)\end{array}$ & $\begin{array}{l}0.011^{* * *} \\
(3.47)\end{array}$ & $\begin{array}{l}-0.009^{* * *} \\
(-4.21)\end{array}$ & $\begin{array}{l}0.003 \\
(1.32)\end{array}$ & $\begin{array}{l}0.004^{*} \\
(1.84)\end{array}$ \\
\hline Pasta & $\begin{array}{l}-0.028^{* * *} \\
(-5.63)\end{array}$ & $\begin{array}{l}-0.008 \\
(-1.05)\end{array}$ & $\begin{array}{l}-0.034 \text { *** } \\
(-6.76)\end{array}$ & $\begin{array}{l}-0.019^{* * *} \\
(-3.42)\end{array}$ & $\begin{array}{l}-0.035^{* * *} \\
(-6.65)\end{array}$ \\
\hline Vegetables & $\begin{array}{l}0.003 \\
(1.16)\end{array}$ & $\begin{array}{l}-0.018^{* * *} \\
(-5.46)\end{array}$ & $\begin{array}{l}0.008^{* * * *} \\
(3.00)\end{array}$ & $\begin{array}{l}0.017^{* * *} \\
(6.10)\end{array}$ & $\begin{array}{l}-0.002 \\
(-0.59)\end{array}$ \\
\hline Sausages & $\begin{array}{l}-0.004 \\
(-1.93)\end{array}$ & $\begin{array}{l}-0.029^{* * *} \\
(-9.87)\end{array}$ & $\begin{array}{l}-0.003 \\
(-1.32)\end{array}$ & $\begin{array}{l}-0.008^{* * *} \\
(-3.57)\end{array}$ & $\begin{array}{l}-0.002 \\
(-0.89)\end{array}$ \\
\hline Milk & $\begin{array}{l}0.002 \\
(0.64)\end{array}$ & $\begin{array}{l}-0.013^{* *} \\
(-2.50)\end{array}$ & $\begin{array}{l}0.008 * \\
(1.82)\end{array}$ & $\begin{array}{l}0.004 \\
(0.89)\end{array}$ & $\begin{array}{l}-0.000 \\
(-0.10)\end{array}$ \\
\hline Sugars & $\begin{array}{l}-0.014^{* * *} \\
(-6.90)\end{array}$ & $\begin{array}{l}-0.024^{* * *} \\
(-8.41)\end{array}$ & $\begin{array}{l}-0.012^{* * *} \\
(-5.85)\end{array}$ & $\begin{array}{l}-0.025^{* * *} \\
(-11.47)\end{array}$ & $\begin{array}{l}-0.009^{* * *} \\
(-4.17)\end{array}$ \\
\hline Soda & $\begin{array}{l}0.001 \\
(0.37)\end{array}$ & $\begin{array}{l}-0.002 \\
(-0.79)\end{array}$ & $\begin{array}{l}-0.001 \\
(-0.54)\end{array}$ & $\begin{array}{l}0.012 \text { *** } \\
(4.79)\end{array}$ & $\begin{array}{l}0.002 \\
(0.78)\end{array}$ \\
\hline$R^{2}$ & 0.15 & 0.22 & 0.18 & 0.17 & 0.13 \\
\hline
\end{tabular}

The evidence reported in the first column in Tables 5 and 6 shows that, once the effect of different control variables was taken into account, the parameter $\delta$ was not significant, indicating that unemployment in the boom period had no causal impact on BMI values, thereby corroborating the evidence reported in Table 4. Contrariwise, the $\gamma$ parameter indicates that, during the bust period, the impact of unemployment status on BMI values was positive and significant (at the $5 \%$ significance level). It can therefore be concluded that the combination of unemployment and economic recession increased BMI values in bust periods relative to boom periods. Furthermore, unemployment had the most impact on BMI values for long-term unemployed or recently unemployed individuals. A plausible explanation — confirmed by lower rates of physical activity in the bust period, $25.6 \%$ versus $58.6 \%$ in the boom period-may be that long-term unemployment during an economic crisis generates a negative shock that leads individuals to neglect their health (see Table 1).

Considering the effects of covariables $X$, the influence of socioeconomic status (reflected in educational level) on BMI values was notable, as individuals with a university education had lower BMI values in both boom and bust periods. This finding corroborates findings by Drewnowski and Specter [17], who reported higher obesity rates among poorer and less well-educated US population subgroups (the outcome of cheaper, more obesogenic diets). Our results are also consistent with those of Urbanos-Garrido and López-Valcarcel [44], who reported that economic crises led to poorer health—although note that these authors studied mental rather than physical health.

\subsection{Difference-in-Differences Evidence via Quantile Regression}

Tables 7 and 8 report the results for DiD via quantile regression for the non-matched and matched samples (using Gaussian kernel matching for the refined control group), respectively, as per Equation (3). 
Table 7. Quantile DiD estimates of the impact of unemployment on BMI for 2006-2007 (boom period) and 2011-2012 (bust period) using non-matched samples.

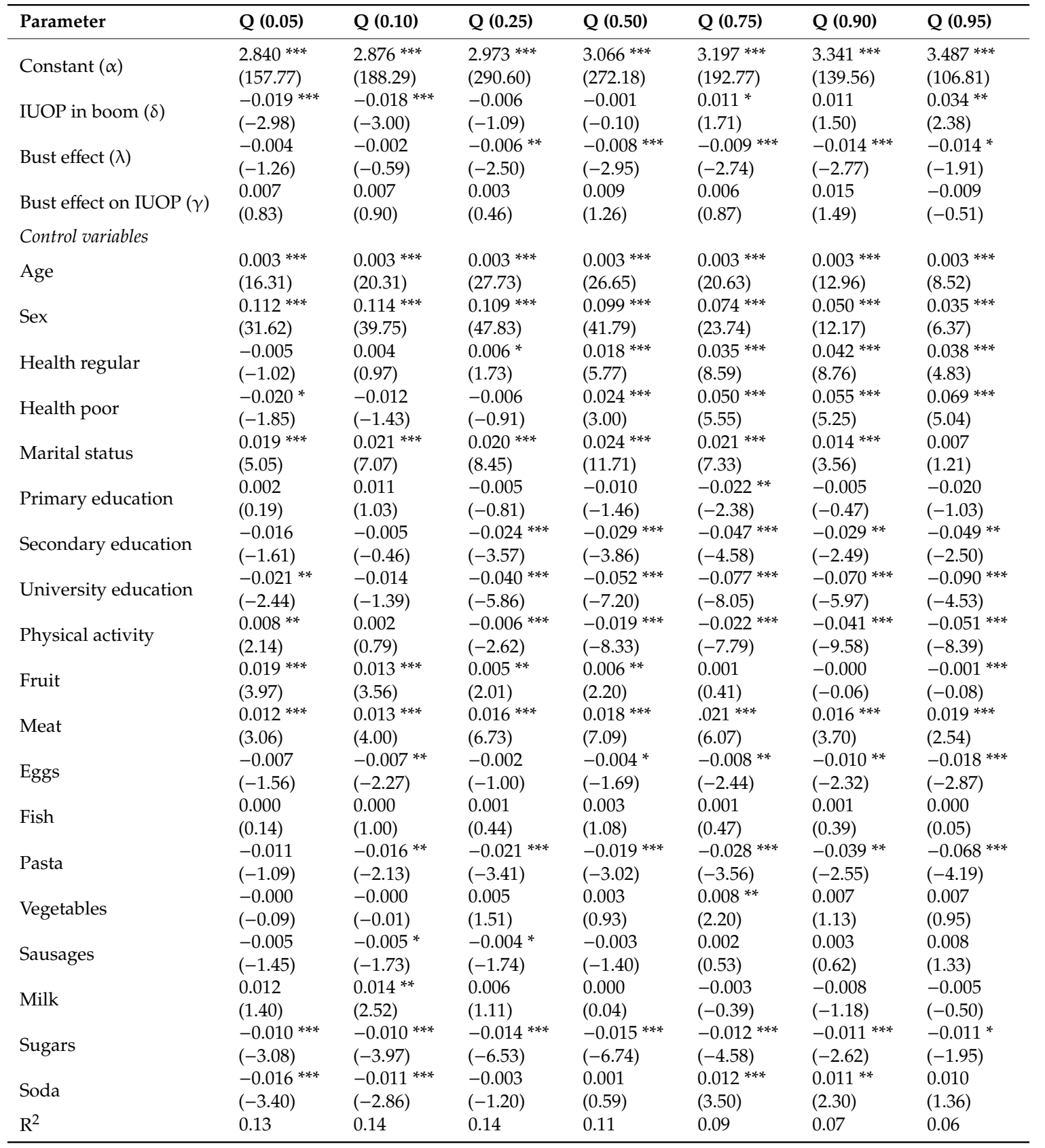

Notes: Quantile DiD model of the impact of unemployment on BMI during the boom for a sample size of 24,613 individuals. Equation (3) in the main text was estimated by controlling for the variables reported in the table and for regional effects (not reported in the table, but available on request). ${ }^{*}{ }^{* *}$ and ${ }^{* * *}$ denote significance at the $10 \%, 5 \%$ and $1 \%$ levels, respectively. 
Table 8. Quantile DiD estimates with Gaussian kernel matching for the impact of unemployment on BMI for 2006-2007 (boom period) and 2011-2012 (bust period).

\begin{tabular}{|c|c|c|c|c|c|c|c|}
\hline Parameter & $Q(0.05)$ & $Q(0.10)$ & $Q(0.25)$ & $Q(0.50)$ & $Q(0.75)$ & $Q(0.90)$ & $Q(0.95)$ \\
\hline Constant $(\alpha)$ & $\begin{array}{l}2.829 * * * \\
(148.36)\end{array}$ & $\begin{array}{l}2.884^{* * *} \\
(190.51)\end{array}$ & $\begin{array}{l}2.983^{* * *} \\
(235.65)\end{array}$ & $\begin{array}{l}3.068^{* * *} \\
(237.25)\end{array}$ & $\begin{array}{l}3.207 * * * \\
(185.88)\end{array}$ & $\begin{array}{l}3.349 * * * \\
(164.77)\end{array}$ & $\begin{array}{l}3.522 * * * \\
(105.73)\end{array}$ \\
\hline Bust effect $(\lambda)$ & $\begin{array}{l}-0.003 \\
(-0.76)\end{array}$ & $\begin{array}{l}0.004 \\
(1.19)\end{array}$ & $\begin{array}{l}-0.002 \\
(-0.87)\end{array}$ & $\begin{array}{l}-0.008^{* * *} \\
(-3.00)\end{array}$ & $\begin{array}{l}-0.013^{* * *} \\
(-3.37)\end{array}$ & $\begin{array}{l}-0.012^{* * *} \\
(-2.69)\end{array}$ & $\begin{array}{l}-0.019 \text { **** } \\
(-2.68)\end{array}$ \\
\hline \multicolumn{8}{|l|}{ Control variables } \\
\hline Age & $\begin{array}{l}0.003 * * * \\
(12.33)\end{array}$ & $\begin{array}{l}0.003 * * * \\
(17.74)\end{array}$ & $\begin{array}{l}0.003^{* * *} \\
(23.59)\end{array}$ & $\begin{array}{l}0.003^{* * *} \\
(25.61)\end{array}$ & $\begin{array}{l}0.003 * * * \\
(16.87)\end{array}$ & $\begin{array}{l}0.003 * * * \\
(14.10)\end{array}$ & $\begin{array}{l}0.003^{* * *} \\
(7.90)\end{array}$ \\
\hline Sex & $\begin{array}{l}0.098^{* * *} \\
(22.97)\end{array}$ & $\begin{array}{l}0.100^{* * *} \\
(29.74)\end{array}$ & $\begin{array}{l}0.097^{* * *} \\
(34.62)\end{array}$ & $\begin{array}{l}0.088^{* * *} \\
(30.96)\end{array}$ & $\begin{array}{l}0.067^{* * *} \\
(17.27)\end{array}$ & $\begin{array}{l}0.041^{* * *} \\
(9.09)\end{array}$ & $\begin{array}{l}0.022 \text { *** } \\
(3.02)\end{array}$ \\
\hline Marital status & $\begin{array}{l}0.020^{* * * *} \\
(4.88)\end{array}$ & $\begin{array}{l}0.023^{* * * *} \\
(6.96)\end{array}$ & $\begin{array}{l}0.020^{* * *} \\
(7.35)\end{array}$ & $\begin{array}{l}0.024^{* * * *} \\
(8.74)\end{array}$ & $\begin{array}{l}0.020^{* * *} \\
(5.38)\end{array}$ & $\begin{array}{l}0.016^{* * *} \\
(3.54)\end{array}$ & $\begin{array}{l}0.007 \\
(0.92)\end{array}$ \\
\hline Primary education & $\begin{array}{l}0.000 \\
(0.05)\end{array}$ & $\begin{array}{l}0.005 \\
(0.68)\end{array}$ & $\begin{array}{l}-0.006 \\
(-0.90)\end{array}$ & $\begin{array}{l}-0.008 \\
(-1.19)\end{array}$ & $\begin{array}{l}-0.012 \\
(-1.30)\end{array}$ & $\begin{array}{l}0.004 \\
(0.40)\end{array}$ & $\begin{array}{l}-0.014 \\
(-0.79)\end{array}$ \\
\hline Secondary education & $\begin{array}{l}-0.019 * \\
(-1.70)\end{array}$ & $\begin{array}{l}-0.010 \\
(-1.15)\end{array}$ & $\begin{array}{l}-0.0211^{* * *} \\
(-2.94)\end{array}$ & $\begin{array}{l}-0.031 \\
(-4.16)\end{array}$ & $\begin{array}{l}-0.037^{* * *} \\
(-3.73)\end{array}$ & $\begin{array}{l}-0.023^{* *} \\
(-2.06)\end{array}$ & $\begin{array}{l}-0.040 \text { ** } \\
(-2.09)\end{array}$ \\
\hline University education & $\begin{array}{l}-0.018 \\
(-1.63)\end{array}$ & $\begin{array}{l}-0.014 \text { * } \\
(-1.67)\end{array}$ & $\begin{array}{l}-0.040^{* * *} \\
(-5.38)\end{array}$ & $\begin{array}{l}-0.052 \text { *** } \\
(-6.78)\end{array}$ & $\begin{array}{l}-0.069 * * * \\
(-6.68)\end{array}$ & $\begin{array}{l}-0.063^{* * *} \\
(-5.34)\end{array}$ & $\begin{array}{l}-0.089 * * * \\
(-4.57)\end{array}$ \\
\hline Physical activity & $\begin{array}{l}0.008 * \\
(1.79)\end{array}$ & $\begin{array}{l}0.006 \text { * } \\
(1.70)\end{array}$ & $\begin{array}{l}-0.008^{* * *} \\
(-2.79)\end{array}$ & $\begin{array}{l}-0.0222^{* * *} \\
(-7.32)\end{array}$ & $\begin{array}{l}-0.032^{* * *} \\
(-7.67)\end{array}$ & $\begin{array}{l}-0.048^{* * *} \\
(-9.98)\end{array}$ & $\begin{array}{l}-0.064^{* * *} \\
(-8.20)\end{array}$ \\
\hline Fruit & $\begin{array}{l}0.030^{* * *} \\
(6.06)\end{array}$ & $\begin{array}{l}0.015^{* * * *} \\
(3.99)\end{array}$ & $\begin{array}{l}0.009^{* * * *} \\
(2.78)\end{array}$ & $\begin{array}{l}0.011^{* * *} \\
(3.31)\end{array}$ & $\begin{array}{l}0.005 \\
(1.10)\end{array}$ & $\begin{array}{l}-0.002 \\
(-0.32)\end{array}$ & $\begin{array}{l}-0.004^{* * *} \\
(-0.43)\end{array}$ \\
\hline Pasta & $\begin{array}{l}-0.017 \\
(-1.83)\end{array}$ & $\begin{array}{l}-0.026^{\text {*** }} \\
(-3.56)\end{array}$ & $\begin{array}{l}-0.022^{* * * *} \\
(-3.31)\end{array}$ & $\begin{array}{l}-0.022^{* * *} \\
(-3.24)\end{array}$ & $\begin{array}{l}-0.027^{* * *} \\
(-2.89)\end{array}$ & $\begin{array}{l}-0.045^{\text {*** }} \\
(-4.17)\end{array}$ & $\begin{array}{l}-0.081 \\
(-4.58)\end{array}$ \\
\hline Vegetables & $\begin{array}{l}0.003 \\
(0.49)\end{array}$ & $\begin{array}{l}-0.002 \\
(-0.43)\end{array}$ & $\begin{array}{l}0.001 \\
(0.27)\end{array}$ & $\begin{array}{l}0.001 \\
(0.33)\end{array}$ & $\begin{array}{l}0.009 * \\
(1.80)\end{array}$ & $\begin{array}{l}0.002 \\
(0.41)\end{array}$ & $\begin{array}{l}-0.005 \\
(-0.50)\end{array}$ \\
\hline Sausages & $\begin{array}{l}-0.009 \text { ** } \\
(-2.19)\end{array}$ & $\begin{array}{l}-0.006 \\
(-1.63)\end{array}$ & $\begin{array}{l}-0.006 \\
(-2.25)\end{array}$ & $\begin{array}{l}-0.006 \\
(-1.93)\end{array}$ & $\begin{array}{l}-0.001 \\
(-0.28)\end{array}$ & $\begin{array}{l}0.005 \\
(1.12)\end{array}$ & $\begin{array}{l}0.013 \text { * } \\
(1.72)\end{array}$ \\
\hline Milk & $\begin{array}{l}0.023^{* * * *} \\
(2.95)\end{array}$ & $\begin{array}{l}0.010 \text { * } \\
(1.72)\end{array}$ & $\begin{array}{l}0.001 \\
(0.28)\end{array}$ & $\begin{array}{l}0.002 \\
(0.32)\end{array}$ & $\begin{array}{l}0.001 \\
(0.18)\end{array}$ & $\begin{array}{l}-0.009 \\
(-1.06)\end{array}$ & $\begin{array}{l}-0.011 \\
(-0.79)\end{array}$ \\
\hline Sugars & $\begin{array}{l}-0.007 \\
(-1.56)\end{array}$ & $\begin{array}{l}-0.010^{* * *} \\
(-3.97)\end{array}$ & $\begin{array}{l}-0.013^{* * *} \\
(-4.68)\end{array}$ & $\begin{array}{l}-0.017 \\
(-6.02)\end{array}$ & $\begin{array}{l}-0.018^{* * *} \\
(-4.78)\end{array}$ & $\begin{array}{l}-0.011 \\
(-2.52)\end{array}$ & $\begin{array}{l}-0.008 \\
(-1.03)\end{array}$ \\
\hline Soda & $\begin{array}{l}-0.010 \\
(-2.21)\end{array}$ & $\begin{array}{l}-0.009^{* *} \\
(-2.35)\end{array}$ & $\begin{array}{l}-0.004 \\
(-1.28)\end{array}$ & $\begin{array}{l}0.004 \\
(1.21)\end{array}$ & $\begin{array}{l}0.011^{* *} \\
(2.44)\end{array}$ & $\begin{array}{l}0.010^{* *} \\
(1.80)\end{array}$ & $\begin{array}{l}0.001 \\
(0.18)\end{array}$ \\
\hline $\mathrm{R}^{2}$ & 0.11 & 0.12 & 0.12 & 0.10 & 0.08 & 0.06 & 0.06 \\
\hline
\end{tabular}

Notes: Quantile DiD model to estimate the impact of unemployment status on quantiles of (log) BMI in an economic recession. We used Gaussian kernel matching with a common support of 24,589 observations (the common support discarded 3 out of 4,119 unemployed individuals and 21 out of 20,494 employed individuals). Equation (3) was estimated by controlling for the variables reported in the table and for regional effects (not reported in the table, but available on request). ${ }^{* * *}$ and ${ }^{* * *}$ denote significance at the $10 \%, 5 \%$ and $1 \%$ levels, respectively.

Estimates for the $\delta_{\tau}$ parameter confirm that unemployment status during the boom period had a significant negative (positive) impact on BMI values for lower (upper) (log) BMI quantiles, independently of whether we used the non-matched or matched samples. The results, thus, confirm that, in boom times, unemployment reduces BMI levels for individuals in lower BMI quantiles and increases BMI levels for individuals in upper BMI quantiles. However, regarding the IUOP during the bust period, our $\gamma_{\tau}$ parameter estimates indicate that the economic crisis reinforced the magnitude of 
the IUOP in the upper-median BMI quantile. Thus, the positive effect of unemployment on BMI values in the bust period was significant for individuals whose BMI values were in the upper-median quantile.

\section{Conclusions}

We analyzed the impact of unemployment status on obesity prevalence (IUOP) and assessed how the magnitude of the IUOP might differ in a boom versus a bust period. This issue is undoubtedly relevant in a context, like that of Spain, where obesity increased from $12.4 \%$ in $2006-2007$ to $14.5 \%$ in 2011-2012 (representative years of a boom and bust period, respectively). Therefore, understanding the factors that condition rising obesity and BMI levels in economic recessions represent a potentially important contribution to our understanding of various aspects of obesity as a pandemic, not only in Spain, but also across the world. Before the economic crisis that unfolded from 2008, the fact that $58.6 \%$ of working-age Spaniards were physically active in their spare time, compared to only $25.6 \%$ after recession onset, would suggest that reduced activity levels had a bearing on rising obesity and BMI levels.

Our main findings show that while unemployment did not significantly impact on the BMI levels of unemployed people in a boom period, but did have a significant impact in a bust period. More specifically, unemployment in the boom period had no causal effect on obesity. However, the advent of an economic crisis increased the $(\log )$ BMI values of individuals who had been unemployed during the previous boom by 0.007 -and by as much as 0.011 for long-term unemployed individuals. Moreover, unemployment has the most impact on BMI values for long-term unemployed or recently unemployed individuals. This result would suggest that the physical health of occupationally active individuals is impaired once they become unemployed during an economic crisis and also that this effect is positive and significant.

We also show that the socioeconomic status (reflected in educational level) had a notable impact on BMI values, as individuals with a university education had lower BMI values in both boom and bust periods. Likewise, certain socioeconomic and lifestyle characteristics were significant risk factors for obesity. Not being university-educated or physically active, in particular, significantly increase BMI levels. This link between education and health parallels similar findings by previous studies $[56,57]$. The increase in BMI values among unemployed individuals during a crisis period as compared to a boom period could be a consequence of weight gain associated with lowered morale, reduced physical activity and neglected health with the advent of an economic crisis.

Overall, our work suggests that, in order to prevent and combat obesity, public policies should be differentially designed according to the phase of the economic cycle and should aim specifically at the long-term unemployed in bust periods. Measures to promote healthy lifestyles should particularly target sedentary, long-term unemployed individuals with lower education levels during crisis times. Thus, rather than a long-term health policy that indistinctly covers boom and bust periods, a shorter term policy and adjusted to the specific phase of the cycle through which the economy goes through might be more effective. Our conclusions are aligned with those of Suhrcke and Stuckler [58], who propose that public health policies should focus on preventing health deterioration in particularly vulnerable populations, including the unemployed and lower socioeconomic groups. Beyond this, what our research highlights is that such measures might also be tailored to the particular phase of the economic cycle.

Author Contributions: M.A. conceived the study and were in charge of overall direction and planning; P.M. participated in the design of the study, performed the analytic calculations and helped to draft the manuscript; J.C.R. participated in the design of the study, performed the analytic calculations and helped to draft the manuscript; F.R.-S. participated in the design of the study, performed the analytic calculations and helped to draft the manuscript. All authors read and approved the final manuscript.

Funding: The authors received funding from the Xunta de Galicia through Grant 2019-GPC Análise Económica dos Mercados e Institucións (AEMI).

Acknowledgments: M.A., P.M. and J.C.R. acknowledge financial aid received from the Xunta de Galicia through Grant 2019-GPC Análise Económica dos Mercados e Institucións (AEMI). 
Conflicts of Interest: The authors declare that they have no competing interests.

\section{Abbreviations}

BMI: Body mass index IUOP: Impact of unemployment on obesity prevalence ATT: Average treatment effect on the treated DiD: Difference-in-differences PSM: Propensity score matching WHO: World Health Organization

\section{References}

1. Darmon, N.; Drewnowski, A. Does social class predict diet quality? Am. J. Clin. Nutr. 2008, 87, 1107-1117. [CrossRef]

2. Hemphill, E.; Raine, K.; Spence, J.C.; Smoyer-Tomic, K.E. Exploring obesogenic food environments in Edmonton, Canada: The association between socioeconomic factors and fast-food outlet access. Am. J. Health Promot. 2008, 22, 426-432. [CrossRef]

3. Moulin, J.J.; Labbe, E.; Sass, C.; Gerbaud, L. Job insecurity, unemployment and health: Results from the health examination centers of the French General Health Insurance. Rev. Epidemiol. Sante Publique 2009, 57, 141-149. [CrossRef]

4. Deb, P.; Gallo, W.T.; Ayyagari, P.; Fletcher, J.M.; Sindelar, J.L. The effect of job loss on overweight and drinking. J. Health Econ. 2011, 30, 317-327. [CrossRef]

5. Muenster, E.; Rueger, H.; Ochsmann, E.; Letzel, S.; Toschke, A.M. Association between overweight, obesity and self-perceived job insecurity in German employees. BMC Public Health 2011, 11, 162. [CrossRef]

6. Hofmeister, M. Health in the long-term unemployed. Higher risk of obesity. Dtsch. Arztebl. Int. 2013, 110, 676.

7. Latif, E. The impact of macroeconomic conditions on obesity in Canada. Health Econ. 2014, 23, 751-759. [CrossRef]

8. Schnuerer, I.; Baumann, S.; Haberecht, K.; Gaertner, B.; John, U.; Freyer-Adam, J. Patterns of health risk behaviors among job-seekers: A latent class analysis. Int. J. Public Health 2015, 60, 111-119. [CrossRef] [PubMed]

9. NCD Risk Factor Collaboration (NCD-RisC). Trends in adult body-mass index in 200 countries from 1975 to 2014: A pooled analysis of 1698 population-based measurement studies with 19.2 million participants. Lancet 2016, 387, 1377-1396. [CrossRef]

10. WHO (World Health Organization). Fact Sheet No. 311, Jan 2015. Available online: http://www.who.int/ mediacentre/factsheets/fs311/es/ (accessed on 15 February 2018).

11. Breda, J.; Webber, L. Proportion of Overweight and Obese Males and Females to Increase in Most European Countries by 2030, Say Latest Projections by WHO; World Health Organization: Copenhagen, Denmark; UK Health Forum: London, UK, 2015.

12. National Statistics Institute, INE. 2015. Available online: http://www.ine.es/prensa/np770.pdf (accessed on 17 January 2018).

13. Hernández-Jiménez, S. Fisiopatología de la Obesidad. Gac. Med. Mex. 2004, 140, 27-32.

14. Health Information System. Health Information and Statistics 2013, Trends in the Main Risk Factors for Chronic Diseases, Spain 2001-2011/12; Ministry of Health, Social Services and Equality: Madrid, Spain, 2013.

15. Wardle, J.; Waller, J.; Jarvis, M.J. Sex differences in the association of socioeconomic status with obesity. Am. J. Public Health 2001, 92, 1299-1304. [CrossRef] [PubMed]

16. Sen, J.; Mondal, N.; Dutta, S. Factors affecting overweight and obesity among urban adults: A cross-sectional study. Epidemiol. Biostat. Public Health 2013, 10, 1.

17. Drewnowski, A.; Specter, S.E. Poverty and obesity: The role of energy density and energy costs. Am. J. Clin. Nutr. 2004, 79, 6-16. [CrossRef] [PubMed]

18. Akil, L.; Ahmad, H.A. Effects of socioeconomic factors of obesity rates in forth southern states and Colorado. Ethn. Dis. 2011, 21, 58-62.

19. Sobal, J.; Rauschenbach, B.S.; Frongillo, E.A. Marital status, fatness and obesity. Soc. Sci. Med. 1992, 35, 915-923. [CrossRef]

20. Ball, K.; Mishra, G.; Crawford, D. Which aspects of socioeconomic status are related to obesity among men and women? Int. J. Obes. 2002, 26, 559-565. [CrossRef] 
21. Sartorius, B.; Veerman, L.J.; Manyema, M.; Chola, L.; Hofman, K. Determinants of obesity and associated population attributability, South Africa: Empirical evidence from a national panel survey, 2008-2012. PLoS ONE 2015. [CrossRef]

22. Ruhm, C.J. Healthy living in hard times? J. Health Econ. 2005, 24, 341-363. [CrossRef] [PubMed]

23. Freyer-Adam, J.; Gaertner, B.; Tobschall, S.; John, U. Health risk factors and self-rated health among job-seekers. BMC Public Health 2011, 11, 659-668. [CrossRef] [PubMed]

24. Komlos, J.; Carson, S. The BMI values of the lower classes likely declined during the great depression. Econ. Hum. Biol. 2017, 26, 137-143. [CrossRef] [PubMed]

25. Benavides, F.G.; García, A.M.; Sáez-Lloret, I.; Librero, J. Unemployment and health in Spain. The influence of socio-economic environment. Eur. J. Public Health 1994, 4, 103-107. [CrossRef]

26. Ross, C.; Mirowsky, J. Does employment affect health? J. Health Soc. Behav. 1995, 36, 230-243. [CrossRef] [PubMed]

27. Dooley, D.; Fielding, J.; Levi, L. Health and unemployment. Annu. Rev. Public Health 1996, 17, 949-965. [CrossRef] [PubMed]

28. Pharr, J.R.; Moonie, S.; Bungum, T.J. The impact of unemployment on mental and physical health, access to health care and health risk behaviors. ISRN Public Health 2012, 2012, 483432. [CrossRef]

29. Urbanos, R.; González, B. Desempleo y salud: Un análisis de la repercusión de la crisis económica sobre la salud de los españoles. Estud. Econ. Appl. 2013, 31, 303-326.

30. Ásgeirsdóttir, T.L.; Corman, H.; Noonan, K.; Reichman, N.E. Lifecycle effects of a recession on health behaviors: Boom, bust, and recovery in Iceland. Econ. Hum. Biol. 2016, 20, 90-107. [CrossRef]

31. Crost, B.; Friedson, A. Recessions and health revisited: New findings for working age adults. Econ. Hum. Biol. 2017, 27, 241-247. [CrossRef]

32. Caliendo, M.; Lee, W.-S. Fat chance! Obesity and the transition from unemployment to employment. Econ. Hum. Biol. 2013, 11, 121-133. [CrossRef]

33. Zdrojowy-Wełna, A.; Zatońska, K.; Bednarek-Tupikowska, G.; Jokiel-Rokita, A.; Kolackov, K.; Szuba, A.; Bolanowski, M. Determinants of obesity in population of PURE study from Lower Silesia. Endokrynol. Pol. 2018, 69, 644-652. [CrossRef]

34. Noh, J.W.; Kim, J.; Park, J.; Oh, I.H.; Kwon, Y.D. Age and gender differential relationship between employment status and body mass index among middle-aged and elderly adults: A cross-sectional study. BMJ Open 2016, 15, 6-11. [CrossRef]

35. Liu, J.; Li, J.; Yang, L.; He, Y.; Chen, Q.; Tong, Q. Prevalence and Risk Factors of Overweight and Obesity Among Planed Pregnancy Couples in Chongqing City. Wei Sheng Yan Jiu = J. Hyg. Res. 2015, 711-716.

36. Coll, J.L.; del Mar Bibiloni, M.; Salas, R.; Pons, A.; Tur, J.A. The prevalence of excessive weight in Balearic Islands' young and middle-aged women and its association with social and socioeconomic factors: A ten-year trend (2000-2010). BMC Public Health 2015, 15, 837. [CrossRef]

37. Monsivais, P.; Martin, A.; Suhrcke, M.; Forouhi, N.G.; Wareham, N.J. Job-loss and weight gain in British adults: Evidence from two longitudinal studies. Soc. Sci. Med. 2015, 143, 223-231. [CrossRef]

38. Hughes, A.; Kumari, M. Unemployment, underweight, and obesity: Findings from Understanding Society (UKHLS). Prev. Med. 2018, 97, 19-25. [CrossRef]

39. Okop, K.J.; Levitt, N.; Puoane, T. Factors Associated with Excessive Body Fat in Men and Women: Cross-Sectional Data from Black South Africans Living in a Rural Community and an Urban Township. PLoS ONE 2015, 8, 10. [CrossRef]

40. Norte, A.; Sospedra, I.; Ortíz-Moncada, R. Influence of economic crisis on dietary quality and obesity rates. Int. J. Food Sci. Nutr. 2019, 70, 232-239. [CrossRef]

41. Zohoori, N.; Mroz, T.A.; Popkin, B.; Glinskaya, E.; Lokshin, M.; Mancini, D.; Kozyreva, P.; Kosolapov, M.; Swafford, M. Monitoring the economic transition in the Russian Federation and its implications for the demographic crisis. The Russian Longitudinal Monitoring Survey. World Dev. 1998, 26, 1977-1993. [CrossRef]

42. OECD Directorate for Employment, Labour and Social Affairs. Obesity Update. June 2014. Available online: http://www.oecd.org/health/Obesity-Update-2014.pdf (accessed on 29 January 2018).

43. Antentas, J.M.; Vivas, E. Impacto de la crisis en el derecho a una alimentación sana y saludable. Informe SESPAS 2014. Gac. Sanit. 2014, 28, 58-61. [CrossRef]

44. Urbanos-Garrido, R.M.; López-Valcarcel, B.G. The influence of the economic crisis on the association between unemployment and health: An empirical analysis for Spain. Eur. J. Health Econ. 2015, 16, 175-184. [CrossRef] 
45. Böckerman, P.; Ilmakunnas, P. Unemployment and self-assessed health: Evidence from panel data. Health Econ. 2009, 18, 161-179. [CrossRef]

46. Rosenbaum, P.R.; Rubin, D.B. The central role of the propensity score in observational studies for causal effects. Biometrika 1983, 70, 41-55. [CrossRef]

47. Heckman, J.; LaLonde, R.; Smith, J. The economics and econometrics of active labor market programs. In Handbook of Labor Economics; Ashenfelter, O., Card, D., Eds.; Elsevier: Amsterdam, The Netherlands, 1999; Volume 3, pp. 1865-2097.

48. Blundell, R.; Dias, M.C. Alternative approaches to evaluation in empirical microeconomics. J. Hum. Resour. 2009, 44, 565-640.

49. Villa, J.M. Diff: Simplifying the estimation of difference-in-differences treatment effects. Stata J. 2016, 16, 52-71. [CrossRef]

50. Koenker, R. Quantile Regression; Cambridge University Press: New York, NY, USA, 2005.

51. Koenker, R.; D’Orey, V. Algorithm AS 229: Computing regression quantiles. J. R. Stat. Soc. Ser. C Appl. Stat. 1987, 36, 383-393. [CrossRef]

52. Buchinsky, M. Estimating the asymptotic covariance matrix for quantile regression models a Monte Carlo study. J. Econ. 1995, 68, 303-338. [CrossRef]

53. Lobstein, T.; Baur, L.; Uauy, R. IASO International Obesity Task Force. Obesity in children and young people: A crisis in public health. Obes. Rev. 2004, 5, 4-104. [CrossRef]

54. Cole, T.J.; Bellizzi, M.C.; Flegal, K.M.; Dietz, W.H. Establishing a standard definition for child overweight and obesity worldwide: International survey. BMJ 2000, 320, 1240-1243. [CrossRef]

55. Stillman, S.; Thomas, D. Nutritional status during an economic crisis: Evidence from Russia. Econ. J. 2008, 118, 1385-1417. [CrossRef]

56. Grossman, M.; Kaestner, R. Effects of education on health. In Social Benefits Education; Behrman, J.R., Stacey, N., Eds.; University of Michigan Press: Ann Arbor, MI, USA, 1997; pp. 69-124.

57. Groot, W.; van den Brink, M.H. The health effects of education. Econ. Educ. Rev. 2007, 26, 186-200. [CrossRef]

58. Suhrcke, M.; Stuckler, D. Will the recession be bad for our health? It depends. Soc. Sci. Med. 2012, 74, 647-653. [CrossRef] 